\title{
SOME HISTOLOGICAL STUDIES ON THE DIGESTIVE SYSTEM OF THE SPALAX LEUCODON (LESSER BLIND MOLE RAT) INHABIT THE EGYPTIAN NORTH COAST
}

O.S. Tammam ${ }^{1}$, S.A. Emara ${ }^{2}$ and Dalia Abo Sedera ${ }^{1}$

${ }^{I}$ Survey of Natural Resources in Environmental System Dept., Environmental Studies \& Research Institute, University of Sadat City, Egypt.

${ }^{2}$ Cytology \& Histology Dept., Faculty of Veterinary Medicine. University of Sadat City, Egypt.

\section{ABSTRACT}

He aim of the present study is to revealed some anatomical and histological 7 structure of the digestive system of the blind mole rat (spalax leucodon 1 Egyptiac us). Nine blind mole rat of both sex were used for this study the digestive system of the lesser blind mole rat is resemble to that of other rodents except some variations. The lip are very small as a flap of skin .the incisor teeth are long, curved and powerful the stomach is unilocular compound type. The proventriculus is demarcated from the glandular gastric regions by limiting ridge. The glandular region contains simple tubular gland, that lined by three types of cells: mucous neck cells, parietal cells and chief cells. The outer longitudinal muscle layer of both cecum and colon showed teniae .

We can concluded that the digestive system of spalax leucodon egyptiacus is similar to that of other rodents, and observed differences due to adaptation to habitat and their diet.

\section{INTRODUCTION}

The genus spalax contains the blind, fossorial or subterranean mole rats, which are one of several types of rodents that are called mole rats (Macdonaled,2006). in egypt, the lesser blind mole rat (spalax leucodon egyptiacus ) lives in el - dabaa zone, marsa matrouh governorate, in the north coast (Tammam \&Omar ,2009). Their eyes are completely covered by alayer of skin (Richarad Hoath , 2003). The animals use their powerful front teeth for digging through soil (Dewey , 2003; Hutchins , 2004; Schlitter et al ,2008). The digestive tract is an important system in living organisms and plays a vital role in food processing and absorption (Hill et al., 2008) . investigation of digestive system of the lesser blind mole rat is very important, where it is arodent belonging to herbivorus animals which prefer aspecial food such as plant root, tubers and bulbs that graw underground (Dewey ,2003;Hutchins,2004;Shehab , 2004; Ozkan , 2007 ; Schlitter et al., 2008; Tammam \&Omar ,2009 and Tammam \&Refai ,2013).

Several morphological studies have been performed to relate the variation in gastrointestinal structure to different feeding habits (Chivers \&Hladik, 1980 ; Perrin\&Curtis ,1980; langer,2002). However, there is still aneed for the brtter understanding of the digestive system .

The goal of our study is to carry out some morphological and histological investigations of the digestive system of spalax leucodon egyptiacus, which lives in Egypt at the north coast in el - dabaa zone. 


\section{MATERIAL \&METHODS:}

Nine mature apparently healthy lesser blind mole rats (Spalax leucodon egyptiacus) of both sexes were used in this investigation. They were obtained from El- Dabaa zone Marsa Matrouh Governorate, Egypt. The animals were sacrificed after slight anesthesia under chloroform inhalation. The digestive system was dissected and examined anatomically. Small pieces were taken directly after sacrification from different parts of the digestive system of the lesser blind mole rats

and fixed in $10 \%$ neutral buffered formalin. The samples were dehydrated in ascending grades of ethyl alcohol, cleared in xylene and embedded in soft paraffin, then blocked in hard paraffin wax (60 - $62^{\circ} \mathrm{C}$, melting point ). Sections of 5-7 micrometer thick were cut using rotary microtome, and stained with Harri's hematoxylin and eosin, Crossmon's trichrome stain, Alcian blue method "pH 2,5" and Periodic acid Schiff (PAS) technique (Bancroft et al., 1996).

\section{RESULTS:}

\section{1-MACROSCOPICAL OBSERVATION:-}

The oral cavity was bounded by two lips (Fig .3) The upper lip was larger than the lower one; each one was represented by a thin flap of skin surrounding the incisor teeth. The rest of the upper lip appeared as bilateral thickening covered externally with skin and contained with the upper jaw. The incisor teeth were long, curved and separated outside from the rest of the mouth by a flap of skin. So, they are still on the outside when the animal closes its mouth (Fig .3). The tongue was elongated flat and formed from: root, body and tip. The dorsal aspect of the tongue contained slight thickening at the posterior region toward the root represented as elevation or prominence as torus lingue(Fig.4). The stomach was unilocular and appeared as C-shape dilated sac (Figs.1\&2). The wall of the stomach was thin in the proventriculus and thick in the glandular part with folds ( rugae ). The proventriculus was demarcated from the glandular gastric part by clear ridge (limiting ridge) (Fig. 5). The small intestine was divided into three parts; duodenum, jejunum, and ileum (Figs.1\&2). The large intestine was formed from three distinct parts: cecum, colon, and rectum (Figs.1\&2). The liver was large and situated in the right cranial abdominal cavity just behind the diaphragm. The liver was formed from five lobes left, right, right central, spigelian, and caudate lobes. The investigated liver contained gall bladder that presented in a depression in the right lobe of the liver .(Fig .6).

\section{MICROSCOPICAL OBSERVATION:}

Each of two lips was formed from central muscle mass lined internally by mucous membrane and covered externally with skin. The lamina epithelialis of internal surface was formed from stratified squamous keratinized epithelium. The skin contained hair follicles sweat glands and sebaceous glands. The hair follicles appeared compound, each was formed from groups of hair follicles surrounded by dense fibrous connective tissue capsules (Fig.7). The labial glands were lobulated and mainly mucous in nature. They gave faint reaction to alcian blue stain (Fig .9 ), while they appeared negative with PAS technique. The lamina epithelialis of the tongue was stratified squamous keratinized epithelium. The ventral surface of tongue appeared smooth and thin with thin keratin layer. The dorsal lingual surface was rough and thick with thicker keratin 
layer, it contained lingual papilla. The filiform papillae were predominated on the dorsum of the tongue mainly on tip and body. The filiform papillae were appeared as thread-like projections directed caudally, its connective tissue core was not extended over the dorsal surface of the tongue(Fig.8) .The fungiform papillae were present inbetween the filiform papillae. The central muscle mass of the tongue was formed from striated (skeletal) muscle bundles which arranged in different directions. The tunica mucosa of the esophagus was appeared folded and forming longitudinal folds, the lamina epithelialis was formed from stratified squamous highly keratinized epithelium. The lamina propria was formed from loose connective tissue. The lamina muscularis mucosa was thin layer of smooth muscle bundles. The tunica submucosa formed from loose connective tissue (Fig .10). The tunica muscularis externa appeared thick and formed from two layers, the inner circular and outer longitudinal smooth muscle fibers .The adventitia was noticed in the cervical part of esophagus and was formed from loose connective tissue continued with the other of the neighboring organs. The tunica serosa was appeared in both the thoracic and abdominal parts.

The first region of the stomach was small nonglandular part and was lined by stratified squamous highly keratinized epithelium (Fig.11), while the other region appeared glandular and was lined by simple columnar epithelium (Fig .12). Small redge or limiting ridge of fibrous connective tissue was separated between the nonglandular and glandular gastric regions (Fig $.12)$.

The fundic gland region was the largest zone in the stomach; the lamina propria was appeared thick and occupied by simple branched tubular glands (Fig.13). These tubular glands were lined by mucous neck cells, parietal cells and chief cells. The mucous cell was short columnar cell; its cytoplasm appeared lightly basophilic and contained mucigenous granules. The nuclei were oval in shape and situated toward the base of the cell. The parietal cells were triangular or pyramidal in shape and appeared more obvious, mainly in the body of the tubular gland. Their cytoplasm was more acidophilic, their nuclei were spherical to ovoid in shape and situated toward the base of the cells (Fig. 14). The chief cells were more numerous cells, specially at the body and the base of the tubular glands, the cells were low columnar with lightly basophilic cytoplasm containing granules as zymogenic granules, their nuclei were spherical, vesicular and located toward the base of the cells (Figs.15) .

The intestinal villi of jejunum were more longer than that of duodenum and ileum . The lamina epithelialis was formed from simple columnar cells with brush border on their free surface and goblet cells inbetween(Figs.16). The intestinal glands were appeared in the lamina propria opened at the base of villi in the intervillar spaces. The intestinal glands were appeared as crypts (Fig.16). The Peyer's patches were observed in case of ileum . They were formed from aggregation of lymph nodules and lymphocytes in the lamina propriea and sometimes extended into submucosa. The tunica submucosa was formed from loose connective tissue. In case of dudenum, the submucosa showed mucous submucosal glands .The tunica submucosa appeared free from glands in case of jejunum and ileum.The tunica muscularies externa was formed from two layers of smooth muscle fibers. The tunica serosa of small intestine was thin and formed from loose connective tissue covered with mesotheilum. 
The tunica mucosa of the cecum appeared folded and contained plicae circularis. The lamina epithelialis was simple columnar epithelium with goblet cells inbetween. Lamina propria was formed from loose connective tissue (Fig.17) and occupied by long simple branched tubular glands (intestinal glands. They were lined by simple columnar cells and increased number of goblet cells. The lamina muscularies mucosa was thin and formed from smooth muscle fibers (Figs.17). The tunica submucosa was formed from loose connective tissue (Figs.17).The tunica muscularis externa appeared relatively thin in cecum and thick in colon and rectum. It was formed from two muscular layer of smooth muscle bundles. The outer longitudinal muscle layer contained teniae. Tunica serosa was thin. The mucosal folds of colon were long and less thick than that of the cecum and the plicae circularis were not distinct. The lamina propria contained short intestinal crypts, inbetween them loose connective tissue. The outer longitudinal muscle layer contained tinae coli. The rectum was contained thick tunica mucosa, with few mucosal folds. The lamina epithelialis was simple columnar epithelium with goblet cells (Figs.18).The lamina propria contained short intestinal crypt surrounded by loose connective tissue, also it contained lymph nodules and lymphocytes mainly at the caudal part of the rectum. The anal canal was continued with rectum by recto-anal junction. Its lamina epithelialis was stratified squamous keratinized epithelium. Propria submucosa formed from fibrous connective tissue contained blood vessels, lymph vessels and nerve fibers. Also it contained sebaceous gland. The tunica muscularis was skeletal muscle bundles .

The liver lobules were illdistinct, where the interlobular connective tissue was very few ,but the classical hepatic lobule was appeared as polygonal in shape, its center contained the central vein while the peripheries contained portal zones "portal lobules". The hepatocytes were arranged side by side forming hepatic plates that arranged radially from the central vein toward the periphery of the hepatic lobule ( Fig.19).

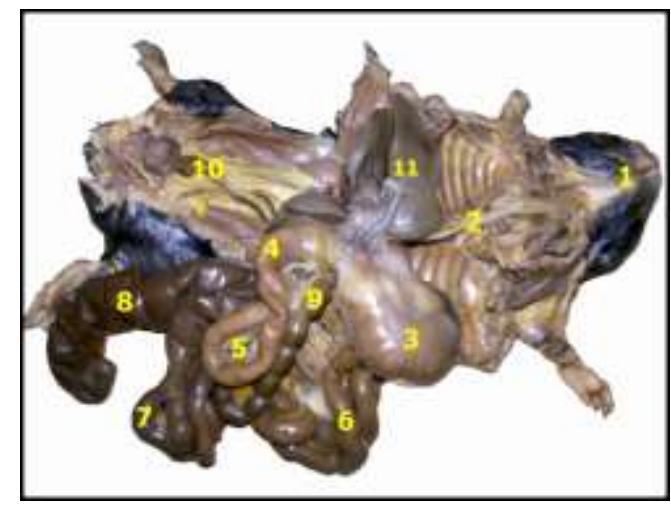

(Fig.1)gross morphology of digestive system tube

Oral cavity (1 ), esophagus ( 2 ), stomach( 3 ), duodenum ( 4 ), pancreas (5), jejunum ( 6 ), ileum ( 7 ), cecum ( 8 )

, colon ( 9 ), rectum ( 10 ) and liver (11).

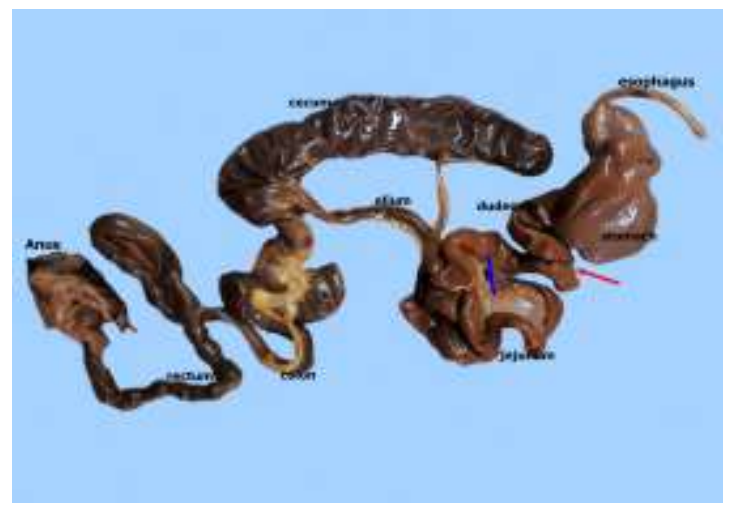

(Fig.2)anatomical structure of gastrointestinal 


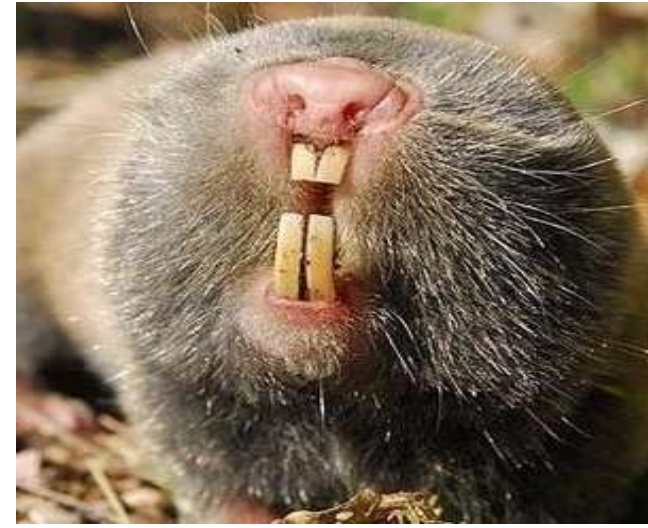

(Fig.3) Face of lesser blind mole rat showing showing long incisor teeth extended outside tongue

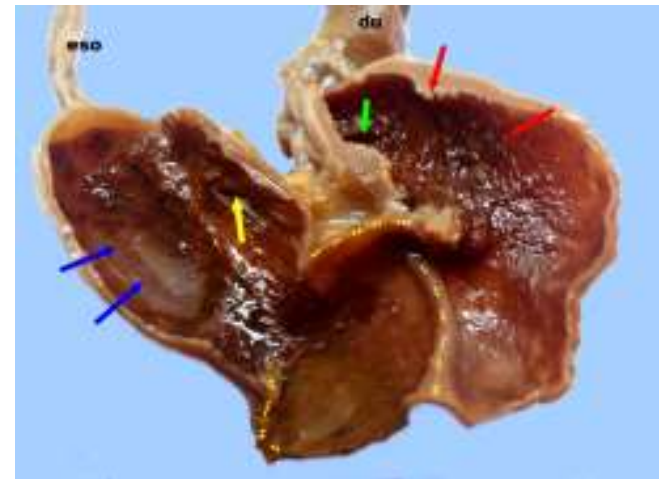

(Fig.5)The inner surface of the stomach,

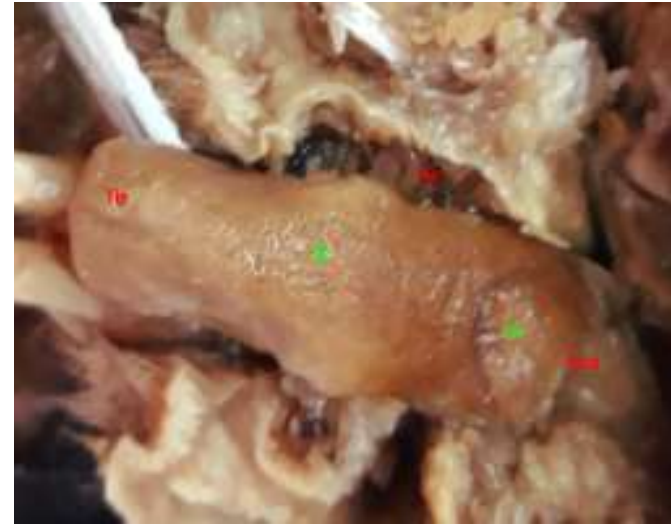

(Fig.4)The tongue of lesser blind mole rat in the lower jaw , showing :- tip, body (*) and root of the ,elevation or prominence (th ), molar teeth (mo ).

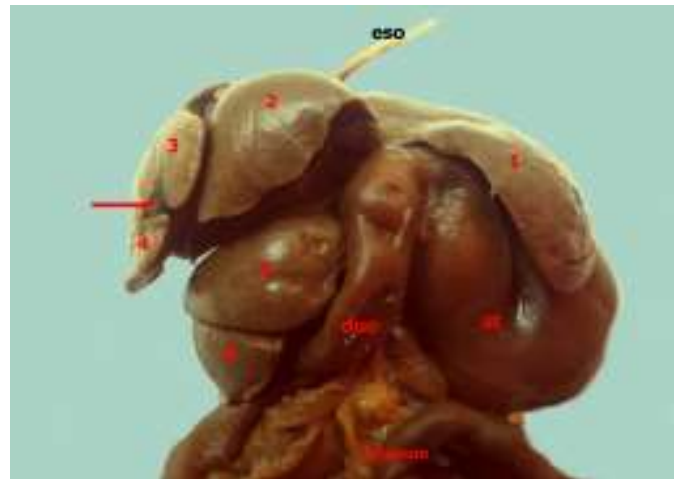

(Fig.6) The liver lobes (1-6) of lesser blind mole rat

showing : gastro-esophageal opening (yellow arrow ), gastro- duodenal opening (green arrow ),smooth surface of nonglandular region (blue arrow ), folded
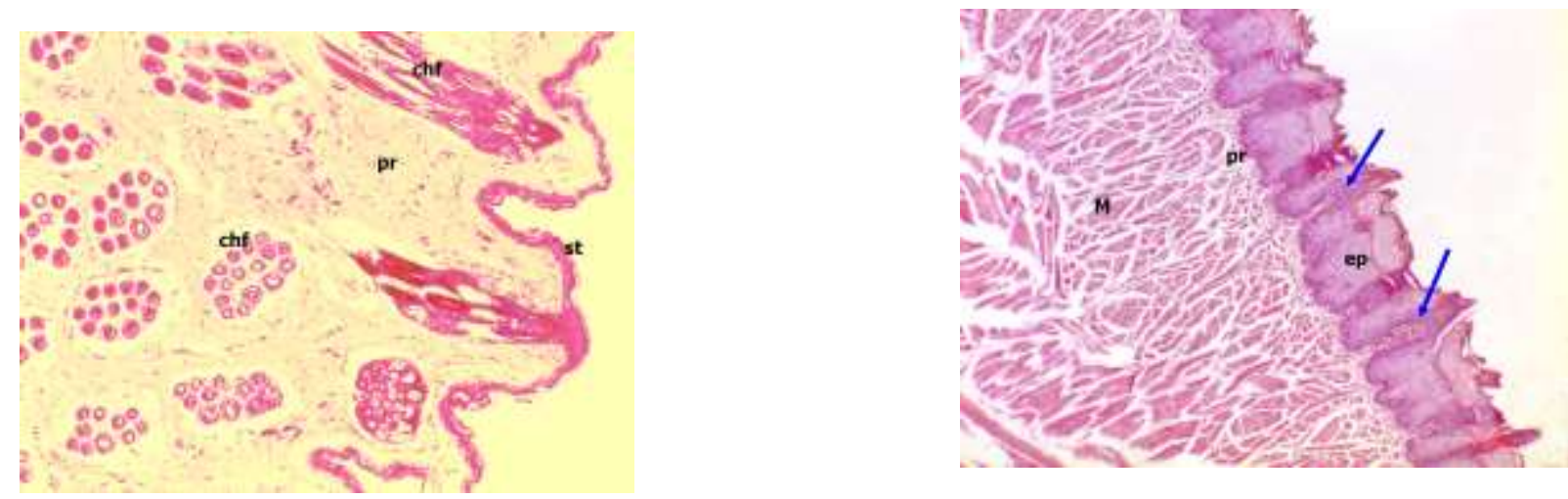

mucosa of the glandular region (red arrow ), the limiting ridge (yellow dotes ) mole rat (spalax leucodon egyptiacus)

(Fig.7)External part of lip of the spalax leucodon muscle mass of skeletal muscle bundles (M) lamina

sebaceous gland ( black arrow ) and compound hair follicles (blue arrow ).
(Fig.8)dorsal surface of the tongue of spalax leucodon filiform papillae (arrow ), dense fibrous connective tissue

propria (pr) and the central muscle mass of skeletal muscle bundles ( $\mathrm{M}$ ) . 


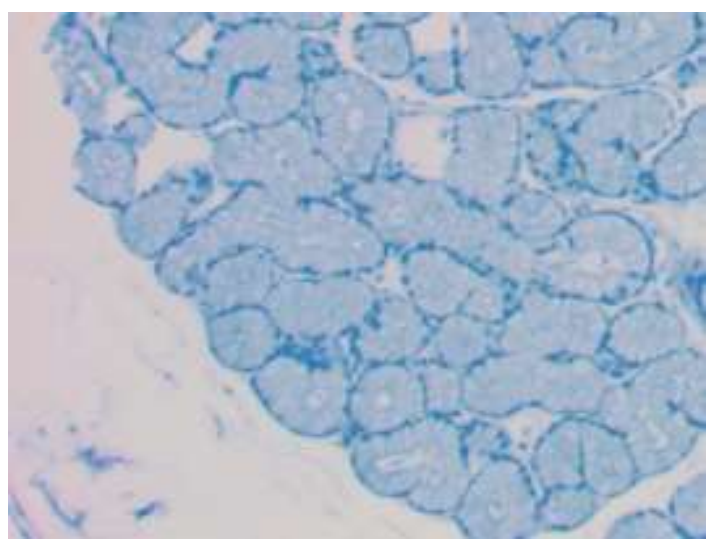

(Fig.9)labial gland of spalax leucodon with faint

Reaction of the alcian blue stain

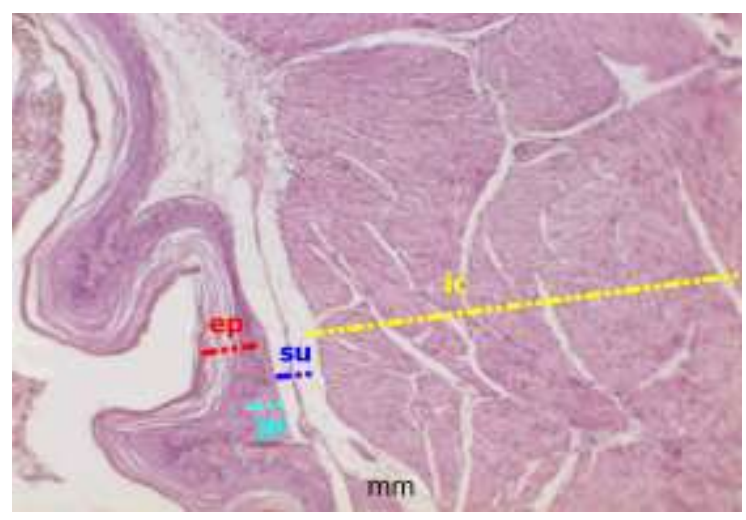

(Fig.11) Non-glandular stomach of lesser blind mole rat Spalax leucodon egyptiacus

non-

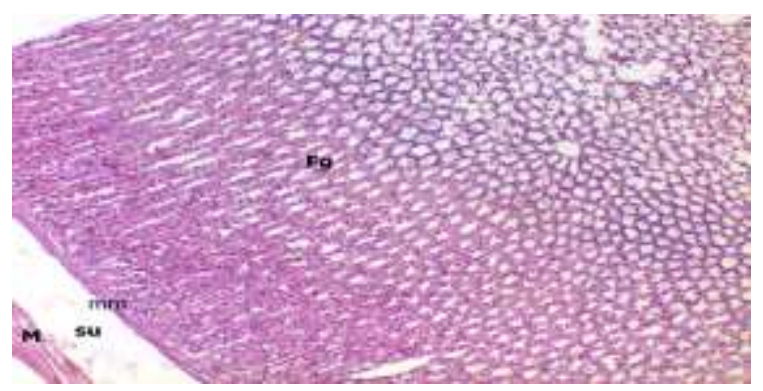

(Fig.13)C.S of simple branched tubular gland of parietal cells

Glandular stomach of the spalax leucodon

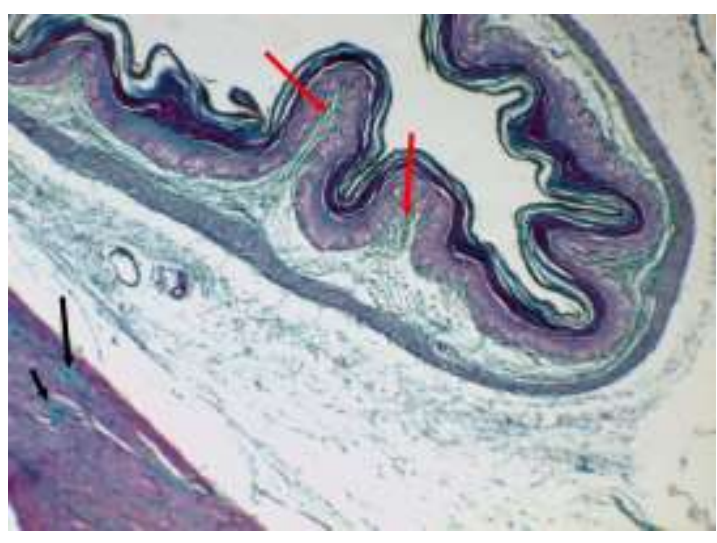

(Fig.10) C.S of the esophagus of spalax leucodon

distribution of collagen fiber Crossmon's trichrome

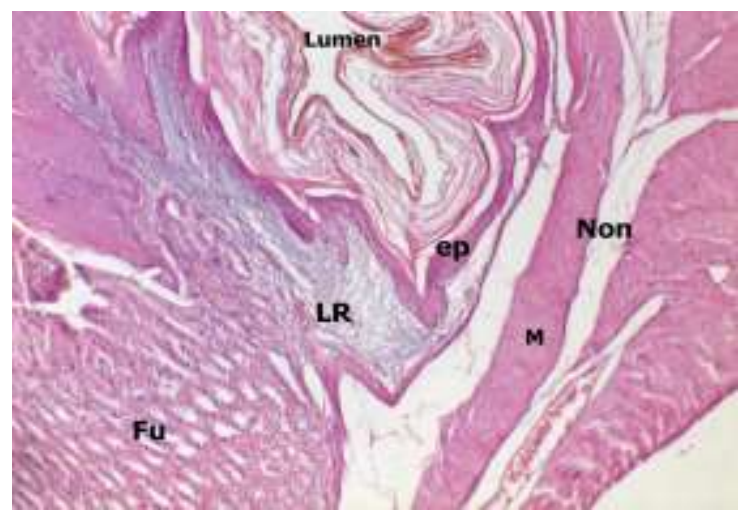

(Fig.12)The junction between the non-glandular and

Glandular Spalax leucodon egyptiacus non0glandular stomach (Non),limiting redge (LR ) separates between the

glandular stomach and glandular stomach (fu ).

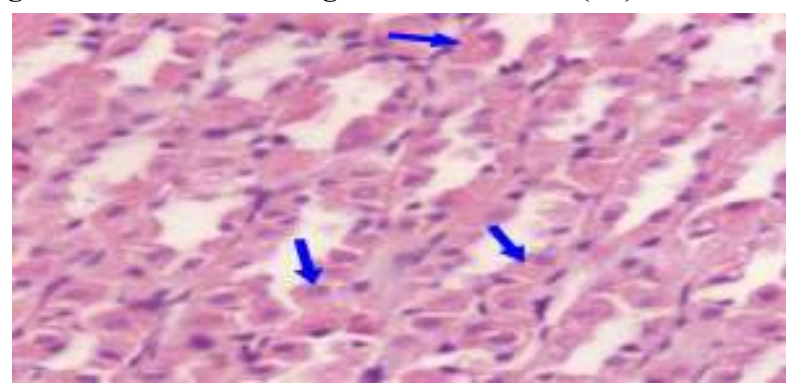

(Fig.14)glandular stomach showing

of the spalax leucodon egyptiacus 


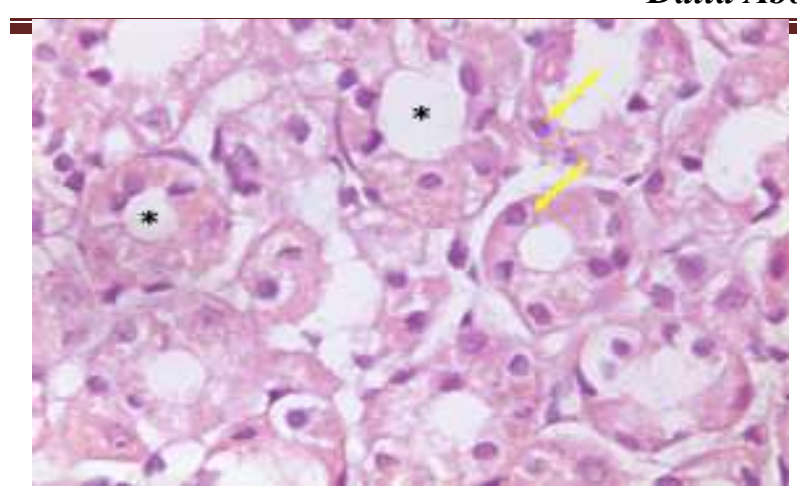

(Fig.15)glandulr stomach showing chief cells of the

Spalax leucodon egyptiacus

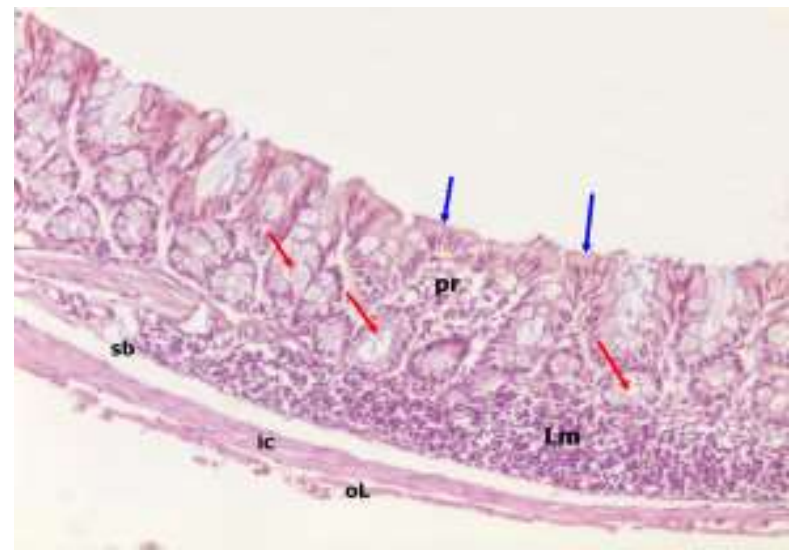

(Fig.17) The rectum of lesser blind mole rat Showing intestinal gland lined bygoblet cell

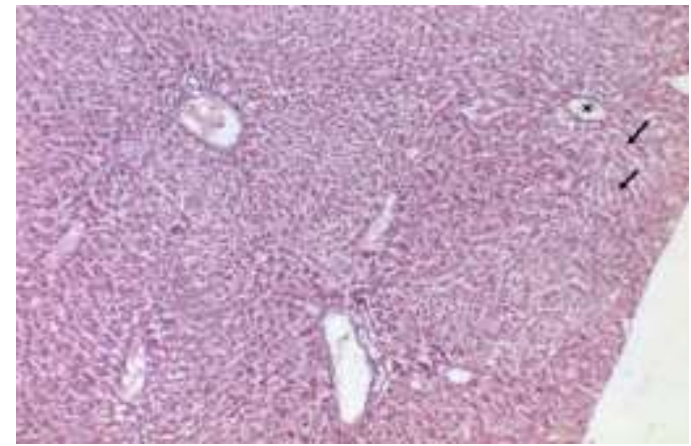

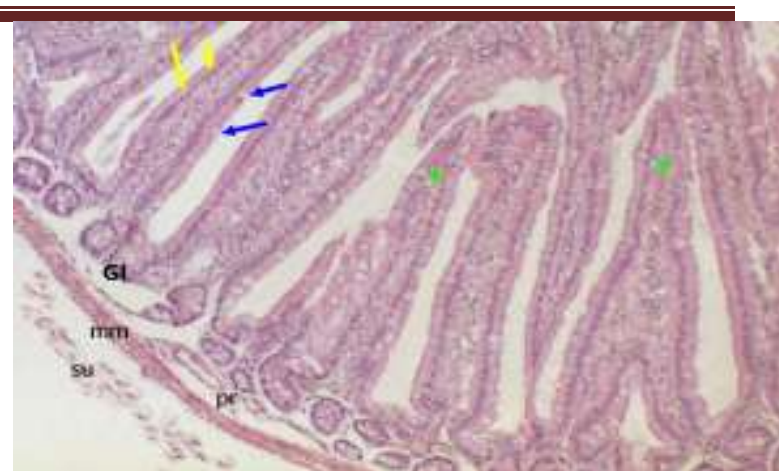

(Fig.16) the jeujenum of the lesser blind mole rat showing long villi and crypts

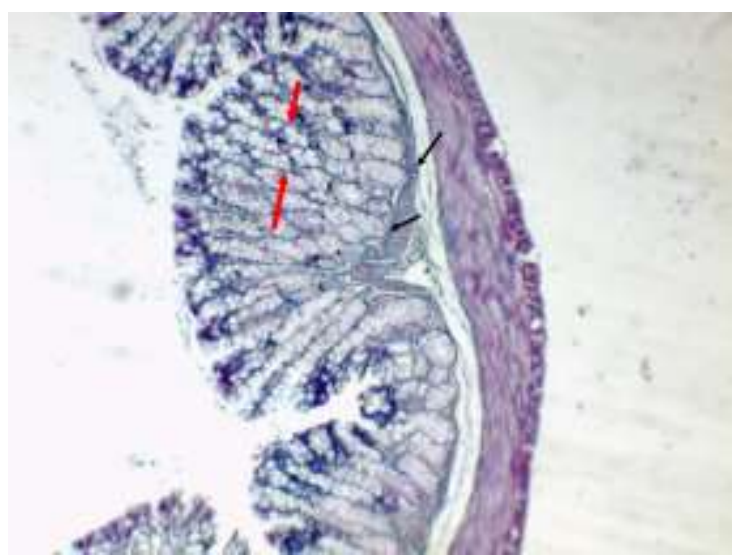

(Fig.18)The cecum of lesser blind mole rat showing collagen fiber in lamina propria with crossmon's

Trichrom stain

(Fig.19) liver of the lesser blind mole rat showing : central vien $(*)$, radiated hepatic plates (arrows) .Note : the interlobular connective tissue is very few so , the lobulation didn't appeared .

\section{DISSCUSION:}

The structure of the gastrointestinal tube of the Egyptian lesser blind mole rat showing similar structure of the other rodent, that was studied by several authors' . (Chivers \& Hladik 1980 ; Ghoshal and Bal .1989 ; Ali et al 2008 ; Nzalak et al 2010 ; Mohamadpour 2011 ; perez et al2011; Boonzaier 2012; AL Mahmodi 2014; Scopin et al 2015). Shehab, (2004) and Ozkan ,2007 mentioned that the upper incisors of mole rat are dorsoventrally directed and the lower incisors are craniodorsally inclined. The present study revealed that the tongue is rounded with rough dorsal surface and contains prominence on its caudal part, the same result was described Nasr et al., 2012 in rat where the anterior margin of the prominence is semicircular 
and rises over the lingual body. we can concluded that the rough dorsal surface and prominence junction for protection. The dorsal surface of the tongue was rough and containing lingual papillae, the same result was mentioned by Nasr et al., (2012)and Ghassemi\&Cheshni (2014) in rat; Erdogan et al., (2015) in Meerkat (Suricata suricatta). While ,Stangl and Pfau (1994) found that the tongue of geomyid and heteromyid, contains lingual papillae on the dorsum and contains on to the sides. The present study showed that the esophagus is musclomembranous tube connects between pharynx and stomach, Nzalak etal.,(2010) in AGR rat \& Scopin et al., (2011) in the Laotian rock rat, mentioned that the oesophagus is rather short and resembles a narrow pipe a short tube extending from the distal end of pharynx to the stomach. The present study showed that stomach of Egyptian lesser blind mole rat is cshaped and formed from one compartment. It is divided into non-glandular and glandular parts by a distinct limiting ridge .the bordering fold stretched from the angular incisures of the lesser curvature to the greater curvature opposite the angular incisures.The same results were recorded by Ghoshal and Bal (1989) in mouse ,rat, hamster and gerbil and Jacklynn et al.,(2014) in different rodents, while the demarcation between non-glandular and glandular parts are not distinct in the stomach of Guinea pigs. The present study showed that the small intestine is divided into non-demarkted three parts duodenum, jejunum and ileum. The same result was mentioned by Ali et al., (2008) in AGR ; Pérez et al.,(2011) in chinchilla . The present study showed that the large intestine is formed from three demarketed parts :caecum ,colon, and rectum . The same result is mentioned by Pérez et al.,(2011) in chinchilla; Stan et al., (2014) in rabbit. The caecum in the Egyptian lesser blind mole rat is well developed and large as in rabbit (Stan et al., 2014) . The present study revealed that the liver of in the lesser blind mole rat is formed from five lobes left, right, right central, spigelian or central, and caudate lobes . The same result was mentioned by Abdel Aziz (1997) in albino rats and Boshra El salkh et al.,(2008) in fat sand rat psammomys obesus. The lamina epithelialis of oral cavity of Egyptian blind mole rat is formed from stratified squamous keratinized epithelium rest on lamina propria of dense fibrous connective tissue. The same finding was recorded by Delalande et al (2014) who added that the rodent species have thiner and keratinized mucosa .

The lamina epithelialis covering the tongue is stratified squamous keratinized epithelium, which is thick with thicker keratin layer on dorsal surface and thin with thinner keratin layer on ventral surface. The dorsal surface is rough and contained lingual papillae. The same structure was mentioned by Jackowiak,\& Godynicki (2005) in the bank vole, Nasr et al (2012) in rat and Mustapha et al.,(2015) in AGR. The filiform papillae are distrubtued on the dorsum of tongue mainly on tip and body, in between them few fungiform papillae. The same result was observed by Nasr et al (2012), Mustapha et al.,(2015) and Erdogan et.al2015 in rat . The esophagus of lesser blind mole rat is lined by stratified squamous keratinized epithelium with thin lamina muscularis mucosae and absence of esophageal glands. This finding conferms the same result which recorded by Wilczynska (1999) in Apodemus flavicollis, Shina et al.,(2004) in rodent, and Scopin et al.,( 2015) in the Laotian rock rat . While, Nzalak et al.,(2010) mentioned that the lining epithelium of the esophagus of African giant rat is non keratinized stratified squamous epithelium with no lamina muscularis and glands. The wall of the stomach of lesser blind mole rat is formed from four basic tunics, from inward outward are mucosa ,submucosa, muscularis and serosa . this conferms the same result in other different 
rodents (Wilczynska ,1999 ; Fairoze khattab ,2007; Ofusori \& Caxton-Martins ,2008; Ali et al., 2008; Laila El - shall ,2010; Eman \& Haider ,2012; Laakkonen et al., 2014; Jacklynn et al., 2014). The parietal cells are large pyramidal in shape with more acidophilic cytoplasm and central ovoid nuclei . these findings equal to the observation in other different rodents (Wilczynska ,1999 ; Fairoze khattab ,2007; Ofusori \& Caxton-Martins ,2008; Ali et al., 2008; Laila El - shall ,2010; Eman \& Haider ,2012; Jacklynn et al., 2014). The wall of the small intestine of lesser blind mole rat of this study is formed from four tunics, inword outword: mucosa, submucosa, muscularis and serosa. The mucosal folds contain finger-like projections (villi) The lamina epithelialis is simple columnar cells with goblet cells inbetween . The intestinal glands appear as crypts and open at the base of villi in the intervillar spaces. The same observations were recorded by (Wilczynska,1999; Ofusori et al., 2008; Nzalak ,2011) in rats. The large intestine of the lesser blind mole rat is characterizied by absence of villi and the presence of numerous goblet cells and intestinal glands . this as that recorded by Nzalak (2011). The present study revealed that the liver of Egyptian blind mole rat is covered by thin dense fibrous connective tissue capsule. The same result is mentioned by (Abdel Aziz,1997; Boshra El- Salkh et al ., 2008; Hanaa Waer\& Seham Helmy ,2012; Safea wally ,2013). The pancreas of the lesser blind mole rat of the present investigation is covered by connective tissue capsule that connected with the interlobular connective tissue septa that divide the pancreas into numerous pancreatic acini and small faint zone of endocrine part of pancreas (islets of langerhans) (Eman ,2008; Moslem and Arrak ,2009; Yasmine ,2011 and Hanaa \& Seham ,2012).

\section{REFERENCE}

1) Abdel Aziz.I (1997) : Histological and Histochemical Changes in the Liver Of Albino Rats Due To Methyl Alcohol Administration, An-Najah Univ. J. Res., Vol. 11, 59-78 .

2) Ali. M. N., O. Byanet, S. O. Salami, J. Imam, S. M. Maidawa, A. D. Umosen, C. Alphonsus and J. O. Nzalak (2008)Gross anatomical aspects of the gastrointestinal tract of the wild African giant pouched rat (Cricetomys gambianus) Scientific Research and Essay Vol.3 (10), pp. 518-520, October 2008.

3) ALMahmodi. A. M. M. (2014) :Histomorphological investigations of the stomach of wild adult male Rabbits(Oryctolagus cuniculus f. domestica)in ALNajaf province. ALQadisiya Journal of Vet. Med. Sci. Vol. 13 No. 2

4) Bancroft, J.D. and Stevens, A. (1996): The haematoxylin and eosin. Theory and practice of histological techniques. 4th ed, Ch 6, pp.99-112. Churchill Livingstone, London, New York \& Tokyo.

5) Boshra A. El- Salkh, Zaki T. Zaki Mohammad I. Basuony and Hanaa A. Khidr (2008) : Anatomical, Histological And Histochemical Studies On Some Organs Of True Desert Rodents In The Egyptian Habitats, The Egyptian Journal of Hospital Medicine Vol., 33: 578- 306.

6) Boonzaier .J (2012):Morphology and Mucin Histochemistry of the Gastrointestinal Tracts of Three Insectivorous Mammals: Acomys spinosissimus, Crocidura cyanea and Amblysomus hottentotus, thesis presented in partial fulfilment of the requirements for the degree of Master of Medical Science in the Faculty of Health Sciences at Stellenbosch University.march 2012.

7) Delalande $\boldsymbol{C}$.T., Fisch $\boldsymbol{C}$, Forster $\boldsymbol{R}$ and Palate B (2014): Comparative Histology of mouth mucosae (sublingual Region), in the annual STP meetings (Washington, US, 22-26/06/2014). 
8) Dewey, T. (2003) : Rats, Mice, and Relatives V: All other rats, mice, and relatives. Pp. 281298 in M Hutchins, A Evans, J Jackson, D Kleiman, J Murphy, D Thoney, eds. Grzimek's Animal Life Encyclopedia, Vol. 16, 2nd ed Edition. Detroit: Gale.

9) Eman A. Abdel Fattah ( 2008 ) :Histological and Immunohistochemical Study of Changes in the Albino Rat Pancreas During Aging, Egypt J. Histol. Vol. 31, No.2, Dec:266 - 277.

10) Eman. M. K \&Haider .D. G. (2012 ) :Anatomical and histological study of stomach in adult local rabbits Oryctolagus cuniculus., AlMustansiriyah J.Sci .Vol .23,No7.

11) Erdoğan .S.Lima,M and Pérez .W. (2014):Anatomical and Scanning Electron Microscopic Study of the Tongue in the Meerkat(Suricatasuricatta,Schreber,1776),journal of veterinary medcine .1-9.

12) Fairoze .I.K. Khattab. (2007):Histological and Ultrastructural Studies on the Gastric Mucosa of Rat after Treatment with Ethylene Glycol, Australian Journal of Basic and Applied Sciences, 1(3): 157-168, ISSN 1991-8178

13) Ghassemi.F, Cheshm.G(2014) :Comparative Histologicalstudy of Tongue in two species of rat (Rattus norvegicus \&Rattus Wistar), Cibtech Journal of Zoology ISSN: 2319-3883, 2014 Vol. 3 (2) May-August, pp.13-21.

14) Chivers D.J, Hladik C.M.(1980) :Morphology of the gastrointestinal tract in primates: comparisons with other mammals in relation to diet ,J Morphol. 1980 Dec;166(3):337-86.

15) Ghoshal N. G. and Bal H.S. (1989):Comparative morphology of the stomach of some laboratory mammals ,Laboratory Animals (1989) 23, 21-29.

16) Hanaa F. Waer, Seham A. Helmy (2012) :Cytological And Histochemical Studies On Rat Liver And Pancreas During Progression Of Streptozotocin Induced Diabetes And Possible Protection Using Certain Natural Antioxidants, The Egyptian Journal of Hospital Medicine Vol., 48: 452- 471.

17) Hutchins, M.( 2004): Rats, mice, and relatives V. Pp. 281295 in D Kleiman, V Geist, M Mcdade, eds.Grizimek's Animal Life Encyclopedia, Vol. 16, 2nd Edition. New York: Thomson and Gale.

18) Jacklynn. W, Sumine .M, Olga. J, Nigel .C. B, Abdulaziz. N. A, Osama. B. M, Sanet H. K(2013) :The comparative gastrointestinal morphology of five species of muroid rodents found in Saudi Arabia. Salivary Glands, Naeture and Science; 11(8).

19) Jackowiak .H., Godynicki. S.(2005).:The distribution and structure of the lingual papillae on the tongue of the bank vole Clethrionomys glareolus , Folia Morphol. Vol. 64, No. 4, pp. 326333 .

20) Jayatilaka A.D.P. , Balasu,B.R, .DUNUWILE, K. ,R and BIBLLE, S.W (1967):Histological Studies of the Gastro-Intestinal Tract of the Rat After Poisoning With Tubers of GloriosaSuperba , CBYION J.MBD.SCI.,Vol.XVI,.Nos.1\&2.

21) Laakkonen.J, Kankaanpää.T, Corfe. I. J, Jernvall.J, Keovichit .T. S.K. \&.Hugot .J. P (2014) :Gastrointestinal and dental morphology of herbivorous mammals: where does the Laotian rock rat fit? Ann. Zool. Fennici. 51: 153-161

22) Laila. M. El-Shall ( 2010 ) :Age Related Changes in the Fundic Mucosa of Stomach of Male Albino Rats (Histological and Immunohistochemical Study) . Egypt. J. Histol Vol. 33, No. 1, March: $32-44$.

23) Langer, P (2002):The Digestive Tract and the Life History of Small Mammals. Mammal Review, 32: 107 - 131. 
24) Macdonald, D.. (2006): The Encyclopedia of Mammals. Oxford University Books. Oxford. 203. 0-87196-871-1.

25) Mahran.A. A, Osman. H .H, Abd El-Mawla. A.M. A. and Attia . A. M (2011):Protective Effect of Zinc (Zn) on the Histology and Histochemistry of Liver and Kidney of Albino Rat Treated with Cadmium,Cytology \& Histology, Volume 2 • Issue $4 \bullet$

26) Moslem Z. Z. and Arrak J.K. (2009) :Structural and functional changes of adrenal cortex and pancreas in mature male rats due to (Curcuma Longa) Al- Anbar J. Vet. Sci., Vol.: 2 No. (1)

27) Mohamadpour .A.A (2011): Morfological and histochemical study of Gunea Pig duodenal submucosal glands, bulgarian Journal of Veterinary Medicine , , 14, No4, 201-208

28) Mustapha.O. A, Ayoade .O. E., Ogunbunmi. T. K. \& OLUDE. M. A. (2014):Morphology of the oral cavity of the African giant rat (Cricetomys Gamblanus, Proceedings of the Zoological Institute RAS Vol. 315, No. 1, pp. 3-18.

29) Nasr, E. S, Gamal, A.M. and Elsheikh, E.H (2012) :Light and scanning electron microscopic study of the dorsal lingual papillae of the rat Arvicanthis niloticus(Muridae, Rodentia), Journal of American Science, 2012;8(4) .

30) Nzalak, James Oliver(2010):Anatomical and Histochemical Studies Of The Digestive System Of The African Giant Rat (Cricetomys gambianus - Waterhouse). Department of veterinary anatomy,faculty of veterinary medicine, Ahmadu Bello University ,Zaria.

31) Nzalak, J. Oliver, Onyeanusi, B. Izuchukwu, Samuel A. Ojo, Voh, A. Ambrose and Ibe, C. S(2010): Gross Anatomical, Histological and Histochemical Studies of the Esophagus of the African Giant Rat (AGR) (Cricetomys gambianus-Waterhouse, 1840) J. Vet. Anat. Vol 3 No 2, $55-64$.

32) Nzalak, J. Oliver., Onyeanusi, B. Izuchukwu., Samuel A. Ojo., Voh A. Ambrose and Ibe, C. Samuel (2011) :Histological and Histochemical Studies of the Colon in the African Giant Rat (Cricetomys gambia-nus, Waterhouse 1840). J. Vet. Anat .Vol 4 No 1, $1-10$.

33) Ofusori D. A. \& Caxton-Martins, E. A.( 2008 ): A Comparative Histomorphometric Study of the Stomach of Rat (Rattus norvegicus), Bat (Eidolon helvum) and Pangolin (Manis tricuspis) in Relation to Diet, Int. J. Morphol., 26(3):669-674,

34) Ofusori, D. A; Caxton-Martins, E. A .Komolafe, O. O.; Oluyemi, K. A.; Adeeyo, O. A.; Ajayi, S. A.; Oluwayinka, P. O.; Adelakun, E. A.; Keji, S. T. \& Adesanya, O. A. ( 2008 ) :A Comparative Study of the Ileum in Rat (Rattus norvegicus), Bat (Eidolon helvum) and Pangolin (Manis tricuspis) as Investigated Using Histological Method, Int. J. Morphol., 26(1):137-141.

35) Pérez, W., Vazquez, N. and Jerbi, H. J. Morphol (2011):Gross anatomy of the intestine and their peritoneal folds in the chinchilla (Chinchilla lanigera). Sci., vol. 28, no. 3, p. 180-183.

36) Perrin .M.R \&Curtis, B.A (1980): Comparative morphology of the digestive system of 19 species of south African myomorph rodents in relation to diet evolution S.A jr .Jzad .15:2233.

37) Richard Hoath (2003) : A field guide to the mammals of Egypt. Cairo ; New York : American University in Cairo Press.

38) Safea .k.wally(2013):Histological study of the native rabbit liver .Elqadesaea vet, J.vol12.no.2. 
39) Schlitter, D., G. Shenbrot, B. Kryštufek, M. Sozen.( 2008) :"Spalax ehrenbergi. In: IUCN 2008. 2008 IUCN Red List of Threatened Species" (Online). Accessed March 30, 2009 at http:// www.iucnredlist.org/details/14326

40) Scopin . A.E, A.P. Saveljev, N.A. Suntsova, S. Gnophanxay, A.N. Tikhonov and A.V. Abramov (2011) :Digestive system of the laotion rook rat LAONASTES AENIGMAMUS (Rodentia: Diatomyidae) from the evolutionary view point. Laonastes aenigmamus (Rodentia: Diatomyidae).vertebrate zoology ,65 (1):151-163.

41) Scopin .A.E,Gashkova .I.V ,Saveljev .A .P, Abramov .A.V(2015):Histologic features of the gastrointestinal tract of Laonastes aenigmamus (Rodentia: Diatomyidae) VERTEBRATE ZOOLOGY 151-163-65(1).

42) Shams I, Avivi A, Nevo E.(2004):Hypoxic stress tolerance of the blind subterranean mole rat: expression of erythropoietin and hypoxia-inducible factor 1 alpha. Proc Natl Acad Sci U S A. 2004;101(26):9698-9703.

43) Shehab.A. H. (2004):The Efficacy of Aluminum Phosphide, Brodifacoum and Floucomafen against the Mol Rat Spalax leucodon Nordmann, 1840 in Syria. Proceedings of the Zoological Institute RAS Vol. 315, No. 1, pp. 3-18.

44) Shina.T, shimizu.Y, Izumi.N, Suzuki.Y, Asano.M, Atoji.Y, Nikami.H and Takewaki.T (2005): Acomparative histological study on the distribution of satiated and smooth muscles and gands in the esophagus of wild birds and mammals, j.vet. med.sci 67 (1):115-117.

45) Stan.F, Damlan.A, Gudea.A, Dezdrobitu.C, Bob.D, Martonos.C,Bochis.I\& Pogana.B(2014):Comparative Anatomical Study of the Large Intestine in Rabbit and Chinchilla, Bulletin UASVM Veterinary Medicine 71 (1), 208-212.

46) Stangl .F. B., Jr. and Pfau .R.S. (1994) :Gross Morphology and Distribution Patterns of Lingual Papillae in Some Geomyid and Heteromyid Rodents, Proc. Okla. Acad. Sci. 74: 25-29

47) Tammam. O.A,Omar. H .M (2009):A New Record for the Lynxacarus in the Egyptian Lesser Blind Mole (Spalax Leucodon Egyptiacus) European Journal of Scientific Research ISSN 1450-216X Vol.33 No.3, pp.509-514.Tammam,O. A. and Refai , M. (2013) :Dual mycotic pulmonary granulomas caused by alternarla alternata and aspergillus candidus in the wild egyption mole rat (spalax leucodon egyptiacus) Assiut Vet. Med. J. Vol. 59 No. 139 .

48) Wilczynska, B. (1999) : Histometry and surface area of the alimentary canal of Apodemus flavicollis , Acta Theriologica 44 (1): 2 9-36.

49) Yasamin .T. Qadori (2011) : Histological Studies on Pancreatic Tissue in Diabetic Rats by Using Wild Cherry, the IRAQI postgraduate medical journalVOL.10, NO.3. 